\title{
First record of the stone crayfish in the Romanian lowlands
}

\author{
Marius-Ioan Groza ${ }^{1, *}$, Diana Cupșa ${ }^{2}$, Leona Lovrenčić ${ }^{3}$ and Ivana Maguire ${ }^{3}$ \\ ${ }^{1}$ University of Oradea, Doctoral School of Biomedical Sciences, Domain: Biology, 1, Universităţii, 410087 Oradea, Romania \\ ${ }^{2}$ University of Oradea, Faculty of Science, Department of Biology, 1, Universităţii, 410087 Oradea, Romania \\ ${ }^{3}$ University of Zagreb, Faculty of Science, Department of Biology, Rooseveltov trg 6, 10000 Zagreb, Croatia
}

Received: 26 April 2021 / Accepted: 21 June 2021

\begin{abstract}
The stone crayfish is a native European freshwater species with significant population declines caused by anthropogenic pressure onto its habitats, climate change and spreading of non-indigenous invasive crayfish and their pathogens (e.g., Aphanomyces astaci). We present the first record of an Austropotamobius torrentium population in a small stream from the southern lowlands of Romania, in an area without limestone or karst, known as a typical stone crayfish habitat in this country. No additional populations were found in the neighbouring streams. The mtDNA analysis based on sequencing a short fragment of the cytochrome c oxidase subunit I (COI) gene revealed that specimens from this newly discovered population belongs to the most widespread phylogroup of $A$. torrentium (CSE) and share the same haplotype as the specimens found in Croatia. Unfortunately, this crayfish population has disappeared most likely because of the crayfish plague since pathogen A. astaci was isolated from moribund crayfish. Our study highlights the vulnerability of isolated relic populations in the face of outside stressors.
\end{abstract}

Keywords: Austropotamobius torrentium / Aphanomyces astaci / karst

Résumé - Premier signalement de l'écrevisse des torrents dans la plaine roumaine. L'écrevisse des torrents est une espèce d'eau douce européenne indigène dont les populations connaissent un déclin important en raison de la pression anthropique sur ses habitats, du changement climatique et de la propagation d'écrevisses invasives non indigènes et de leurs agents pathogènes (par exemple, Aphanomyces astaci). Nous présentons le premier enregistrement d'une population d'Austropotamobius torrentium dans un petit ruisseau des basses terres du sud de la Roumanie, dans une zone sans calcaire ni karst, connue comme un habitat typique de l'écrevisse des torrents dans ce pays. Aucune autre population n'a été trouvée dans les ruisseaux voisins. L'analyse de l'ADNmt basée sur le séquençage d'un court fragment du gène de la sous-unité I de la cytochrome c oxydase (COI) a révélé que les spécimens de cette population nouvellement découverte appartiennent au phylogroupe le plus répandu d'A. torrentium (CSE) et partagent le même haplotype que les spécimens trouvés en Croatie. Malheureusement, cette population d'écrevisses a disparu très probablement à cause de la peste des écrevisses depuis que l'agent pathogène $A$. astaci a été isolé des écrevisses moribondes. Notre étude met en évidence la vulnérabilité des populations relictuelles isolées face aux facteurs de stress extérieurs.

Mots-clés : Austropotamobius torrentium / Aphanomyces astaci / karst

Freshwater crayfish are an old group of invertebrates, with different adaptive potentials (Reynolds et al., 2013). They generally inhabit fresh waters with heterogeneous substrate that provides shelters (Füreder et al., 2006), and are mostly negatively influenced by organic and inorganic pollutants (Reynolds et al., 2013). Climate change, deforestation, habitat deterioration and introduction of the alien invasive crayfish species to their environment negatively affect their chances of survival (Holdich et al., 2009).

\footnotetext{
*Corresponding author: mariusioan.groza@yahoo.com
}

The stone crayfish (Austropotamobius torrentium) is one of the most threatened crayfish species in Europe (Streissl and Hodl, 2002), mostly due to human impact onto their natural habitats (Maguire et al., 2018). This species is a complex of genetically divergent phylogenetic groups (Klobučar et al., 2013; Pârvulescu et al., 2019; Lovrenčić et al., 2020), with typically high environmental requirements. It is most commonly present in cold (Souty-Grosset et al., 2006), well-oxygenated waters (Pârvulescu et al., 2011), with moderate current velocities (Pockl and Streissl, 2005). It mostly prefers habitats with hard substrate (Bohl, 1988) and a 


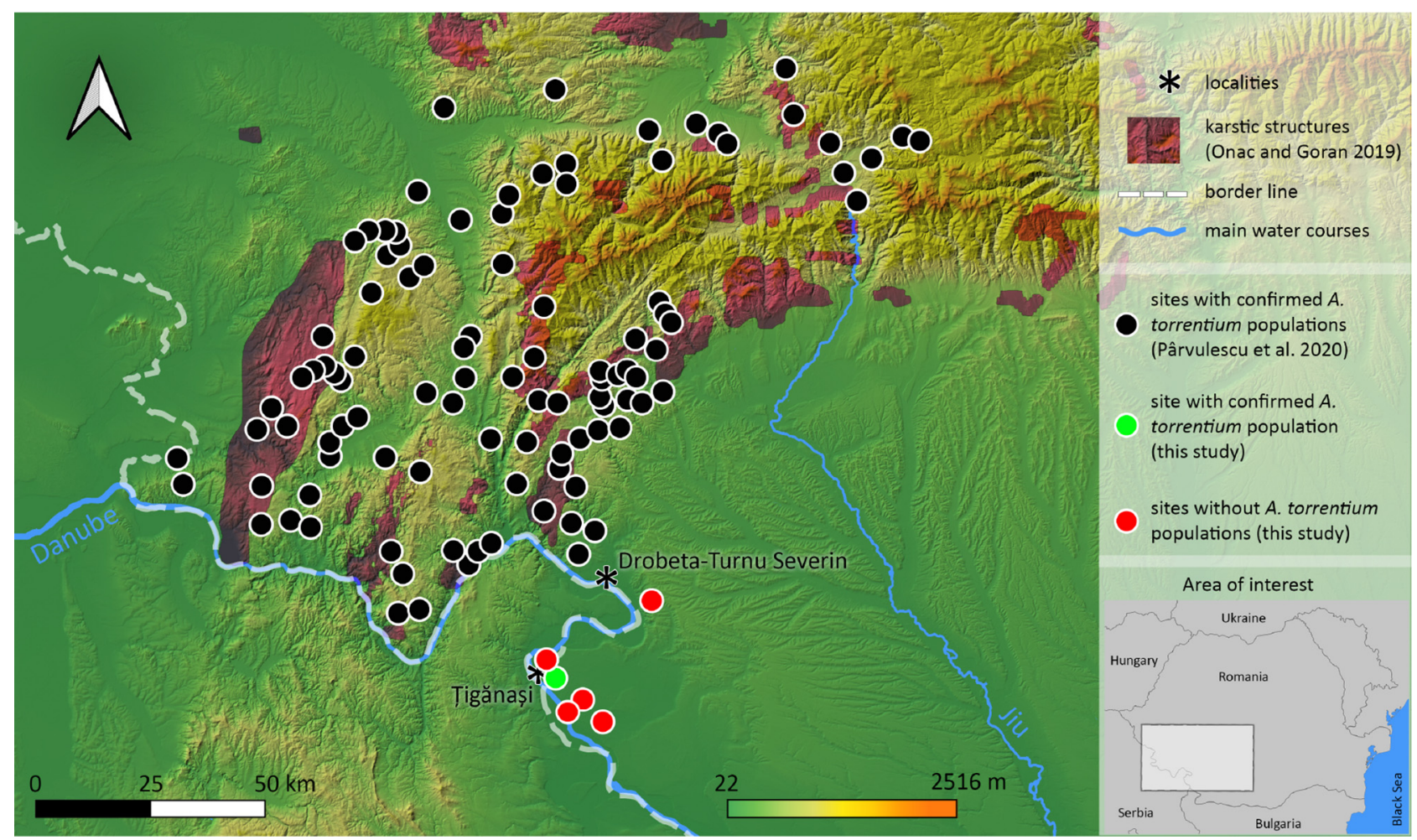

Fig. 1. The map was made using QGIS 3.16.1-Hannover version and GIMP 2.10.22 version. It was designed by the superimposition of the A. torrentium distribution map from Pârvulescu et al. (2020) and the karstic structures map from Onac and Goran (2019).

high number of suitable stone shelters (Vlach et al., 2009; Pârvulescu et al., 2016). Due to their environmental requirements and negative anthropogenic pressure onto their habitats, this species has a fragmented dispersal across its distribution range (Kouba et al., 2014). According to recent studies (Klobučar et al., 2013; Pârvulescu et al., 2019, Lovrenčić et al., 2020), A. torrentium most likely began its spread from the Dinarids (in early Miocene) towards eastern and southern Europe via pre-glacial and post-glacial dispersal routes, later linked to the Danube River and its tributaries that enabled its dispersal into central Europe (Klobučar et al., 2013), reaching its northernmost limits of distribution in the Rhine and Elbe River Basins (Petrusek et al., 2017).

Previous molecular studies established that the population of the stone crayfish in the south-western part of the Carpathians in Romania belongs to the central-south European (CSE) phylogroup sensu Klobučar et al. (2013). Stone crayfish migrated to that region via the Danube River system (Pârvulescu et al., 2019; Lovrenčić et al., 2020), and survived Pleistocene glaciations due to suitable refuge habitats (Pârvulescu et al., 2013). Currently, these populations' distribution is limited to mountainous and sub-mountainous karstic regions (Pârvulescu et al., 2013, 2020). Presently, their survival is confined by the presence of co-occurring species: Astacus astacus and recently introduced Faxonius limosus (Pârvulescu et al., 2009, 2011). The later species, is also a carrier and a spreading vector of the pathogen Aphanomyces astaci that is a causative agent of crayfish plague (Kozubíková et al., 2011), disease that is most frequently lethal for native crayfish species and subsequently poses one of the most serious threats to their survival (Jussila et al., 2017). Faxonius limosus carrying the pathogen has colonised a long stretch of the Danube River in Romania (Pârvulescu et al., 2012), but, to our knowledge, there is no published evidence about its contact with the populations of $A$. torrentium in the small tributaries of the Danube, nor is there any mention of the $A$. astaci infection within the stone crayfish populations from the aforementioned streams.

In this study, we present the first report of an A. torrentium population in the lowlands of Romania (an altitude of $40-50 \mathrm{~m} / \mathrm{asl})$. This population was discovered in 2018 in a small stream, in the Blahnița Plain, near Tigănași Village, approximately $50 \mathrm{~km}$ away from the mountains and the karstic habitats (Fig. 1). This stream is a small tributary of the Danube River and is connected to a series of irrigation channels. It flows into the Danube River $2.2 \mathrm{~km}$ downstream from Țigănași Village (Fig. 2). The last $500 \mathrm{~m}$ of the stream (section WSWC in Fig. 2), close to its mouth, possess conditions similar to typical stone crayfish habitat, with coarse sand and gravel, small to medium sized stones as a substrate and many larger stones, randomly spread throughout the stream. Upstream part of this stream is different (section WSHC in Fig. 2); a smoother substrate of sand with silt and steeper banks with tree roots rising from the water. This, approximately $4.5 \mathrm{~km}$ stretch of the stream (sections: WSWC, WSHC, Fig. 2), is surrounded by an alder grove. The crayfish searches were made only in the last two downstream sections (WSWC, WSHC) because section BSWC, situated upstream from WSWC and WSHC, was 


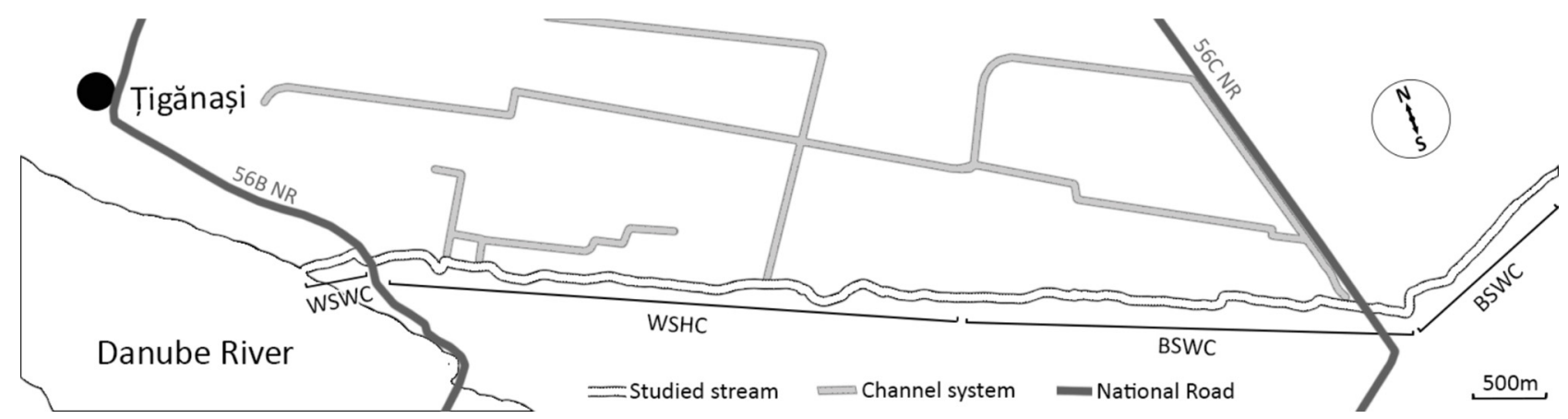

Fig. 2. The map of the studied stream containing the most important roads that pass over it and the manmade artificial channels it connects with; WSWC - wooded section without crayfish; WSHC - wooded section harbouring crayfish; BSWC - barren section without crayfish.

lacking tree coverage and was vastly affected by agriculture. Crayfish were caught only in the WSHC section of the stream with no recorded findings in the WSWC section, even though the conditions in WSWC section seem to be more suitable for this species. Five, apparently healthy looking, individuals and nine in poor health condition (limp or dead), were caught. The crayfish were captured by hand and were $7-10 \mathrm{~cm}$ long (total length, from the tip of the rostrum until the end of telson).

Samples (the distal segment of pereiopod five) for mtDNA COI analysis were taken from the healthy crayfish. Since crayfish in the poor health condition showed gross signs of crayfish plague (numerous melanisations on the carapace and pereiopods), we also sampled them/removed them from the stream for later laboratory analyses. Both sample types were preserved in the $95 \%$ alcohol until laboratory processing.

In order to establish crayfish phylogenetic position samples were processed and analysed according to procedure described in Lovrenčić et al. (2020). Obtained COI sequences were collapsed into already described haplotype AT108 that belongs to CSE phylogroup sensu Klobučar et al. (2013) (Appendix 1).

In order to test sampled tissues for A. astaci we followed procedure of Pavić et al. (2020). Analysis showed that sampled stone crayfish were infected by $A$. astaci and their poor health status and observed mass mortality was a consequence of crayfish plague outbreak. The pathogen load was level A2 what disabled genotyping (Vrålstad et al., 2009).

The search for this $A$. torrentium population was repeated twice during October (mating time/period of crayfish high activity) 2020, but not a single crayfish was captured. Furthermore, 4 similar looking streams in the proximity were also thoroughly searched for the presence of the crayfish (Fig. 1), with the same outcome. Even though, three out of the four additional streams run directly into the Danube River (where F. limosus was observed - personal observations), there were no records of this invasive species within any of them. This absence of crayfish in all of these four additional streams is most probably linked to the fine grain substrate, the high velocity shallow water throughout most of the watercourses and the lack of suitable shelters or banks suitable for burrowing. Also, crayfish absence could have been a consequence of anthropogenic pressure onto the habitat since these streams are surrounded by settlements and agriculture land.

Guarding in mind previously adduced, a question that arises is: How did the population of $A$. torrentium get to the stream near Țigănași? Their presence in Romania is related to their past migrations in the Miocene-Pleistocene period, when they also colonised the southern part of the Carpathians through the Danube River and its tributaries (Lovrenčić et al., 2020; Pârvulescu et al., 2020). Thus, the most probable explanation for their discovery away from the expected areas could be the close relation of this species to the Danube River system. Stone crayfish populations might have been widespread in the streams of this area, but only the T,igănași population survived.

This claim is also supported by the molecular phylogenetic analysis (Appendix 1). This population is part of the CSE clade sensu Klobučar et al. (2013), together with all the stone crayfish populations within the southern Carpathians, in Romania (Pârvulescu et al., 2020), and are also closely related to some populations in Croatia (Lovrenčić et al., 2020). The Danube River changed its course throughout the Pleistocene period, starting from its most north-eastern location in the Günz ice age and reaching its most south-western position (the current location) after the last glaciation (Würm) (Răducă et al., 2019). The Danube might have played an essential dualistic role in the spread of the crayfish, firstly, by acting as a refuge during the glaciations and secondly, by being a strong barrier in the migration path of the animals coming from the Carpathians, in the north. Thus, the A. torrentium population near T,igănași might have been a relic of the past populations that found refuge in the lower and probably warmer area, of southern Romania. Similar patterns of settling into lower elevations with a milder climate, during the ice ages as a survival mechanism/strategy, were also recorded for numerous plant and animal taxa. For example, trees from genus Fagus can be found here, at lower altitudes than expected (Pascovschi, 1967). Also, species classified as mountainous, like some terrestrial isopods, Hyloniscus transsilvanicus and Ligidium germanicum (Ferenţi and Covaciu-Marcov, 2014) and Salamandra salamandra (Covaciu-Marcov et al., 2017), were also found in the Blahnița Plain region. Another important finding that supports our hypothesis is the presence of Mesoniscus graniger (Ferenți and Covaciu-Marcov, 2018) in the Blahniţa Plain. This isopod species was thought to be related only to the caves in the mountainous karstic region, until it was discovered in the lowlands. The presence of Darevskia praticola in the open areas near streams of this region (Covaciu-Marcov et al., 2009), is also very important, proving that these areas used to be covered with forests, that 
are known as factors that enable stable conditions in freshwater habitats (Beschta, 1991).

And yet we cannot rule out possibility that the Țigănași population was of anthropogenic origin, but we could not find any written evidence in the literature that would support this hypothesis.

The presence of $A$. astaci in the studied stream was established, but pathogen level was too low and we could not determine its genotype. We can only presume that it belongs to Or genotype (haplogroup E) that is connected to the spinycheek crayfish (Kozubíková et al., 2011) distributed in the vicinity (the Danube River). Infection could only have occurred recently, since $F$. limosus was seen in 2015 (Covaciu-Marcov, personal communication) at Portile de fier II, a village located on the bank of the Danube River, $13 \mathrm{~km}$ downstream from the studied stream. Aphanomyces astaci have reached Drobeta-Turnu Severin in 2014 (Pârvulescu et al., 2015), and although there are no recently published updates on the plague spread/distribution, based on the distribution of the spiny-cheek crayfish, we can assume that the plague occurred at the same time as the invader near Țigănași. The spread of the infection into the tributaries is not unexpected (Jussila et al., 2015), taking into consideration that contact with any carrier of $A$. astaci zoospores (crayfish or fish) or fishing equipment could cause a crayfish plague outbreak (Schrimpf et al., 2012; Maguire et al., 2016).

A. torrentium individuals from the mouth of the stream, into the Danube River, might have come into contact with crayfish or other pathogen carriers and become infected first. Consequently, they also died first, explaining the lack of the crayfish in the WSWC section of the stream. The explanation for the lack of $F$. limosus in the stream may be linked to the size of the waterbody, as these crayfish were rarely seen entering and spreading upstream small tributaries (Petrusek et al., 2006).

Our data indicated that $A$. torrentium probably had a historically wider distribution in Romania. Thus, we can infer that the populations here did not only survive in areas with limestone or karst during the Pleistocen glaciations (Pârvulescu et al., 2013). It is possible that the studied population survived until 2018 only by chance, as they only occupied a segment of the stream (4.5 km long) that was not heavily affected by agricultural activity. But unfortunately, isolation, all the outside pressures and lastly, the crayfish plague have led to their demise.

Our report highlights the vulnerability of isolated relic populations in the face of outside stressors, both biotic ( $A$. astaci) and abiotic (anthropogenic pressure onto the freshwater habitats) that frequently lead to their demise.

Acknowledgements. This work was funded by Project 123008 , "SmartDoct - High quality programmes for doctoral and postdoctoral students of Oradea University, for the increase of relevance in research and innovation, in the context of the regional economy", project financed by Human Capital Operational Programme 2014-2020 (for the research carried out by the Romanian team: Marius-Ioan Groza, Diana Cupșa), also it was partially funded by the Croatian Science Foundation (for the research carried out by the Croatian team: CLINEinBIOta - IP-2016-06-2563 to Ivana Maguire, ESF - DOK-2018-01-9589 to Leona Lovrenčić). We would like to thank Adam Peter Maguire for English language editing, and anonymous reviewers for their constructive criticisms.

\section{References}

Beschta RL. 1991. Stream habitat management for fish in the northwestern United States: the role of riparian vegetation. Am Fish $S S$ 10: 53-58.

Bohl E. 1988. Comparative studies on crayfish brooks in Bavaria (Astacus astacus L., Austropotamobius torrentium Schr.). Freshw Crayfish 7: 287-294.

Covaciu-Marcov S-D, Cicort-Lucaciu A-S, Gaceu O, Sas I, Ferenţi S, Bogdan HV. 2009. The herpetofauna of the south-western part of Mehedinţi County, Romania. North-West J Zool 5: 142-164.

Covaciu-Marcov S-D, Sas-Kovács I, Cicort-Lucaciu AȘ. 2017. Lower than the lowest! Relict Salamandra salamandra population in Stârmina Hill, South-Western Romania. Russ J Herpetol 24: 81-83.

Ferenţi S, Covaciu-Marcov S-D. 2014. Relict populations of Hyloniscus transsilvanicus and Ligidium germanicum in the Blahnița Plain, south-western Romania. Spixiana 37: 69-72.

Ferenți S, Covaciu-Marcov S-D. 2018. Beyond the rule: a mountainous cave species, Mesoniscus graniger (Isopoda, Oniscidea) on a plain of south-western Romania. Oltenia, Studii şi Comunicări, Stiiințele Naturii 34: 89-92.

Füreder L, Edsman L, Holdich D, Kozak P, Machino Y, Pockl M, Renai B, Reynolds J, Schulz R, Schulz HK, Sint D, Taugbol T, Trouilhé M-C. 2006. Indigenous crayfish habitat and threats. In Souty-Grosset C, Holdich DM, Noël P, Reynolds JD, Haffner P, eds. Atlas of Crayfish in Europe, Muséum national d' Histoire naturelle, Paris, 25-47.

Holdich DM, Reynolds JD, Souty-Grosset C, Sibley PJ. 2009. A review of the ever increasing threat to European crayfish from nonindigenous crayfish species. Knowl. Manag. Aquat. Ecosyst. 11: 394-395.

Jussila J, Vrezec A, Jaklič T, Kukkonen H, Makkonen J, Kokko H. 2017. Aphanomyces astaci isolate from latently infected stone crayfish (Austropotamobius torrentium) population is virulent. J Invertebr Pathol 149: 15-20.

Jussila J, Vrezec A, Makkonen J, Kortet R, Kokko H. 2015. Invasive crayfish and their invasive diseases in Europe with the focus on the virulence evolution of the crayfish plague. In: Canning-Clode J. ed. Biological Invasions in Changing Ecosystems. Vectors, Ecological Impacts, Management and Predictions. Warsaw: De Gruyter Ltd, 183-211.

Klobučar GIV, Podnar M, Jelić M, Franjević D, Faller M, Štambuk A, Gottstein S, Simić V, Maguire I. 2013. Role of the Dinaric Karst (western Balkans) in shaping the phylogeographic structure of the threatened crayfish Austropotamobius torrentium. Freshw Biol 58: $1089-1105$.

Kouba A, Petrusek A, Kozák P. 2014. Continental-wide distribution of crayfish species in Europe: update and maps. Knowl. Manag. Aquat. Ecosyst. 413: 05-31.

Kozubíková E, Viljamaa-Dirks S, Heinikainen S, Petrusek A. 2011. Spiny-cheek crayfish Orconectes limosus carry a novel genotype of the crayfish plague pathogen Aphanomyces astaci. J Invertebr Pathol 108: 214-216.

Lovrenčić L, Bonassin L, Boštjančić LL, Podnar M, Jelić M, Klobučar G, Jaklič M, Slavevska-Stamenković V, Hinić J, Maguire I. 2020. New insights into the genetic diversity of the stone crayfish: taxonomic and conservation implications. BMC Evol Biol 20: 146.

Maguire I, Jelić M, Klobučar G, Delpy M, Delaunay C, Grandjean F. 2016. Prevalence of the pathogen Aphanomyces astaci in freshwater crayfish populations in Croatia. Dis Aquat Organ 118: 45-53. 
Maguire I, Klobučar G, Žganec K, Jelić M, Lucić A, Hudina S. 2018. Recent changes in distribution pattern of freshwater crayfish in Croatia - threats and perspectives. Knowl Manag Aquat Ecosyst 419: 2.

Onac BP, Goran C. 2019. Karst and Caves of Romania: A Brief Overview. In: Ponta GML, Onac BP. (eds) Cave and Karst Systems of Romania. Springer: Cham, Switzerland, pp. 21-35.

Pârvulescu L, Iorgu EI, Zaharia C. 2020. The future of endangered crayfish in light of protected areas and habitat fragmentation. Sci Rep 10: 14870.

Pârvulescu L, Pacioglu O, Hamchevici C. 2011. The assessment of the habitat and water quality requirements of the stone crayfish (Austropotamobius torrentium) and noble crayfish (Astacus astacus) species in the rivers from the Anina Mountains (SW Romania). Knowl Manag Aquat Ecosyst 401: 3.

Pârvulescu L, Palos C, Molnar P. 2009. First record of the spiny-cheek crayfish Orconectes limosus (Rafinesque, 1817) (Crustacea: Decapoda: Cambaridae) in Romania. North-West J Zool 5: 424-428.

Pârvulescu L, Pérez-Moreno JL, Panaiotu C, Drăguț L, Schrimpf A, Popovici ID, Zaharia C, Weiperth A, Gál B, Schubart CD, BrackenGrissom H. 2019. A journey on plate tectonics sheds light on European crayfish phylogeography. Ecol Evol 9: 1957-1971.

Pârvulescu L, Pîrvu M, Morosan L, Zaharia C. 2015. Plasticity in fecundity highlights the females' importance in the spiny-cheek crayfish invasion mechanism. Zoology 118: 424-432.

Pârvulescu L, Schrimpf A, Kozubíková E, Cabanillas Rsino S, Vrålstad T, Petrusek A, Schulz R. 2012. Invasive crayfish and crayfish plague on the move: first detection of the plague agent Aphanomyces astaci in the Romanian Danube. Dis Aquat Org 98: 85-94.

Pârvulescu L, Zaharia C, Groza MI, Csillik O, Satmari A, Drăguț L. 2016. Flash-flood potential: a proxy for crayfish habitat stability. Ecohydrology 9: 1507-1516.

Pârvulescu L, Zaharia C, Satmari A, Drăguț L. 2013. Is the distribution pattern of the stone crayfish in the Carpathians related to karstic refugia from Pleistocene glaciations? Fresh Sci 32: 1410-1419.

Pascovschi S. 1967. Succesiunea speciilor forestiere, Editura Agrosilvică, Bucharest, 318p. [in Romanian].

Pavić D, Čanković M, Petrić I, Makkonen J, Hudina S, Maguire I, Vladušić T, Švera L, Hrašćan R, Orlić K, Dragičević P, Bielena A.
2020. Non-destructive method for detecting Aphanomyces astaci, the causative agent of crayfish plague, on the individual level. J Invertebr Pathol 169: 107274.

Petrusek A, Filipová 1, Duriš Z, Horká I, Kozák P, Policar T, Štambergová M, Kučera Z. 2006. Distribution of the invasive spiny-cheek crayfish (Orconectes limosus) in the Czech Republic. Past and present. Bull Fr Peche Piscic 380-381: 903-917.

Petrusek A, Pešek P, Leština D, Martin P, Fischer D, Kozák P, Vlach P. 2017. Mitochondrial DNA provides evidence of a double origin for the stone crayfish Austropotamobius torrentium in the Elbe basin. Limnologica 62: 77-83.

Pockl M, Streissl F. 2005. Austropotamobius torrentium as an indicator for habitat quality in running waters. Bull Fr Peche Piscic 376-377: 743-758.

Răducă C, Crisu L, Enache C. 2019. The influence of neotectonics and eustatism on the Danube route in the Blahnița Plain. Muzeul Olteniei Craiova, Oltenia, Studii şi comunicări, Ştiințele Naturii, Tom. 35(2).

Reynolds J, Souty-Grosset C, Richardson A. 2013. Ecological roles of crayfish in freshwater and terrestrial habitats. Freshw Crayfish 19: 197-218.

Schrimpf A, Pârvulescu L, Copilaș-Ciocianu D, Petrusek A, Schulz R. 2012. Crayfish plague pathogen detected in the Danube Delta a potential threat to freshwater biodiversity in southeastern Europe. Aquat Invasions 7: 503-510.

Souty-Grosset C, Holdich D, Noel P, Reynolds JD, Haffner P. 2006. Atlas of crayfish in Europe, Muséum national d'Histoire naturelle, Paris, $188 \mathrm{p}$

Streissl F, Hodl W. 2002. Habitat and shelter requirements of the stone crayfish, Austropotamobius torrentium Schrank. Hydrobiologia 477: 201-208.

Vlach P, Fischer D, Hulec L. 2009. Microhabitat preferences of the stone crayfish Austropotamobius torrentium (Schrank, 1803). Knowl. Manag. Aquat. Ecosyst. 394-395: 1-13.

Vrålstad T, Knutsen AK, Tengs T, Holst-Jensen A. 2009. A quantitative TaqMan (R) MGB real-time polymerase chain reaction based assay for detection of the causative agent of crayfish plague Aphanomyces astaci. Vet Microbiol 137: 146-155. 


\section{Appendix 1}

Phylogenetic tree of $A$. torrentium based on $C O I$ data obtained through Bayesian analysis performed in MrBayes 3.2.6 (Ronquist et al., 2012). The optimal model of nucleotide evolution for $C O I$ data set was $\mathrm{HKY}+\mathrm{I}+\mathrm{G}$, selected under the Bayesian information criterion (BIC) using the jModelTest 2.1.10. (Darriba et al., 2012). The BA priors were set according to the suggested model; two separate runs with four Metropolis-coupled Monte Carlo Markov chains (MMCM) were performed for 10,000,000 generations, and trees were sampled every 1,000 generations. After checking congruence (ESS values > 200) with Tracer v1.7.1 (Rambaut et al., 2018), the first $25 \%$ of sampled trees were eliminated as burn-in, and a tree was constructed, with nodal values representing the posterior probabilities. Numbers at the nodes indicate Bayesian posterior probabilities (values $>0.91$ are indicated). New Romanian sequences belonging to haplotype AT108 are indicated in red colour. Phylogroups are represented by different colour: black - central and south-eastern Europe (CSE), blue - Gorski Kotar (GK), purple - Lika and Dalmatia (LD), orange - Žumberak, Plitvice and Bjelolasica (ŽPB), pink - southern Balkans (SB), green - Banovina (BAN), red - Zeleni Vir (ZV), gray - Apuseni Mountain (APU) and turquoise blue - Kordun (KOR).

\section{References}

Darriba D, Taboada GL, Doallo R, Posada D. 2012. jModelTest 2: more models, new heuristics and parallel computing. Nat Methods 9: 772 .

Ronquist F, Teslenko M, van der Mark P, Ayres DL, Darling A, Höhna S, Larget B, Liu L, Suchard MA, Huelsenbeck JP. 2012. MrBayes 3.2: efficient Bayesian phylogenetic inference and model choice across a large model space. Syst Biol 61: 539-542. 


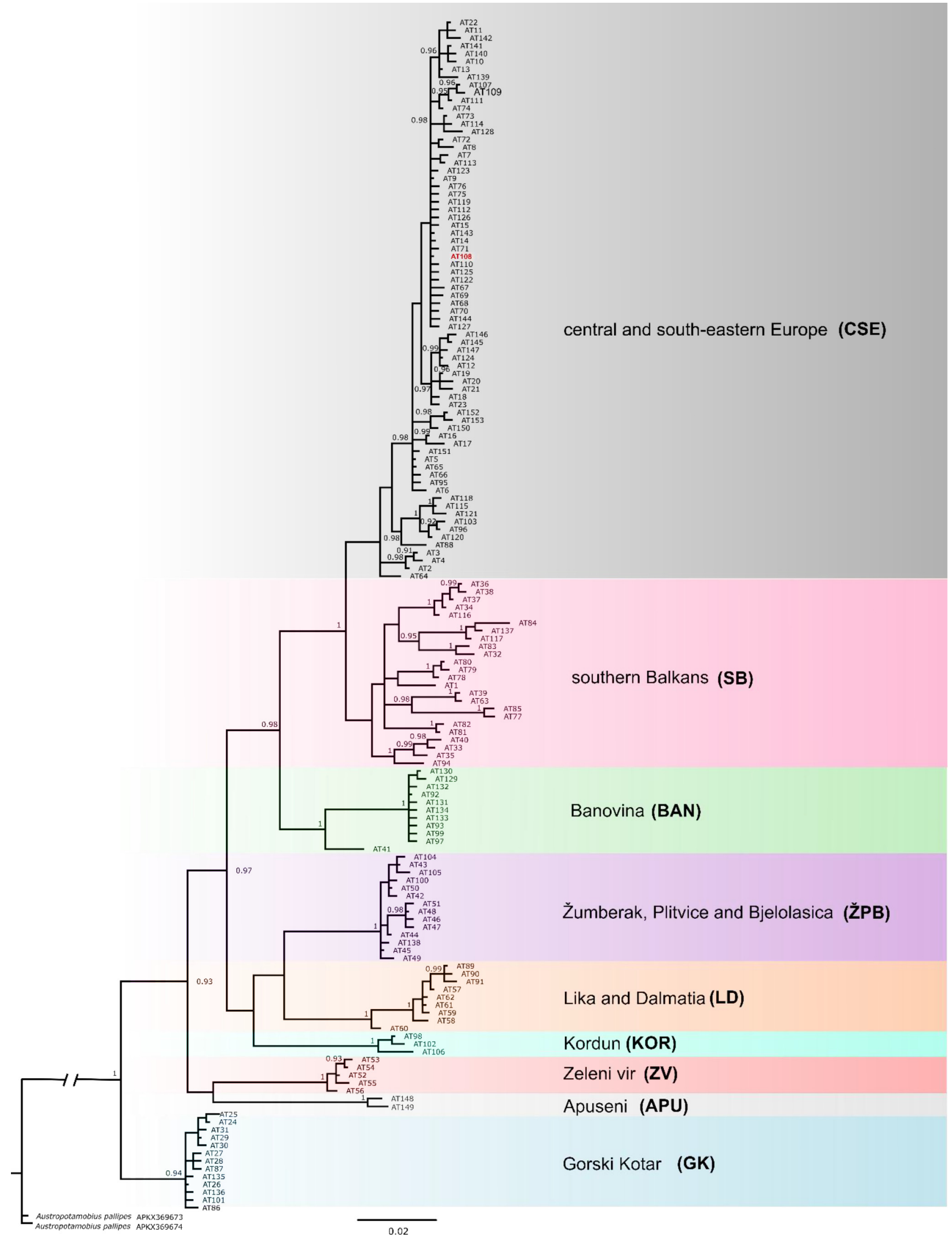

